\title{
An Overview of the Main Phenomena and Trends that Accompanied the Development of Higher Education (1990 - 2013)
}

\author{
Jani Sota \\ Prof. Assoc. Ph.D., \\ "Aleksandër Moisiu" University, \\ Durrës, Albania
}

Doi: 10.2478/ajis-2018-0057

\begin{abstract}
This is now a well known axiom, that to judge the level of emancipation of a particular society, one should know the extent of her education. Because of the system's nature, Albanian and foreign historiography has not been tackling a lot with the problems of higher education after 1990, seeing it from the perspective of the interests of the Albanian democratic state anyway, in terms of the transition, although with difficulties, efforts to change were not interrupted. The transition from totalitarianism to pluralist democracy and a free market economy also raised the issue of a radical change in the education field, a radical restructure, a radical democratic reform throughout work and life. Everything that happened after this period, especially in higher education, destroyed the "foundations" of the traditional high school influence by marxism-leninism, paving the way to new decentralized changes to achieve the highest quality indicators, through the step by step perfection of the university documentation, and efforts for the preparation of specialists, who are able to have direct access in manufacturing as well. The transformation of higher education began when our country was undergoing the transition period. In this study we will focus on the general analysis of the efforts of the Albanian government in front of incomplete standards in the higher educational system, reorganization of the school, in the framework of the change of the political system and the tranformation of socio-economic in Albania. Then it will be elaborated the intensity of changes and the results that are obviously noticed from one stage to the other, also some aspects of the reorganization process and the consolidation of higher education.
\end{abstract}

Keywords: Higher education, standard system, study program, autonomy, academic freedom, students

\section{Introduction}

In Albania, the overthrow of the political-social system and the democratic transformations that occurred after the 1990s dictated the need for a multi-faceted effort to affirm and integrate Albanian education into the European one, in the context of the deep national goals for education. As an arena of numerous and rapid changes in all areas of life, since 1992 Albania began to attempt to reform the education system, particularly the pre-university and university system.

In this context, the new political, economic and cultural reality was increasingly evidenced by the fact that Albanian higher education was subjected to a series of wide-ranging variations of action, complexity and incalculable consequences for its progress within the national education system and Wider. Their essence would consist of focusing on the activity of the democratic state in drafting policies and strategies for a university education on a profoundly European basis. It was the time when the country was going through the transition period. This very difficult period, with significant depressions in politics, economics, social development, education, culture and science, was faced with development strategies supported by foreign donors. Moreover, it should be 
emphasized that "in all countries, the need for higher education reforms matures faster than in the rest of education sytem" (Golemi, 2002).

It seems quite right the efforts of the Albanian state to undertake a reform of democratization and decentralization of the entire education system, especially the pre-university, university and post-university system. Bringing light on this process, the breakdown of the lines and the main factors defined and modeled the policies pursued in this area and their implications on the entire Albanian society of the time, is also the main goal of this paper.

Exactly, the main topic of this scientific monograph is the higher education in Albania in the focus of the Albanian state policies during 1992-2013, with the active participation of the relevant factors. The 1992-2013 period in official documentation is considered as the stage of laying the foundations and consolidating democracy, which coincides with the most important stages of transformation, reform and development of higher education according to a more modeling, planning, administration and effective management. Within it, significant transformations were undertaken, linked to a series of legal and structural reforms, as well as efforts to implement short and long-term strategies that played a special role for the subsequent educational performance in Albania.

The aim of the scientific article is to analyze the development of the Albanian higher education system during the period 1992-2013, focusing on some key issues such as: the emergence of the authoritarian system and the changes that the higher education system has undergone; the implementation of Bologna Process and the effort to become part of EHEA (European Higher Education Area); quality assurance, mobility and credit transfer, social dimensions, lifelong learning, academic freedom and autonomy of $\mathrm{HEl}$, study cycles and adaptation of study programs closely related to the labor market.

Given the wide scope of this subject, I have aimed at exploring on the subject of inherent changes, with the claim of avoiding as far as possible the past and present influences the product of which we all are.

The years 1992-2013, although in the time span represent not a relatively short period, due to the importance of political, social, ideological and educational changes occupy an important place. They marked the beginning of a new period in Albania's history. The inherited level, though low, constituted a basis for further education in Albania.

Any political force that would come to power after the overthrow of the communist dictatorship, in addition to other problems, would have to choose even the ones in the field of education, especially in Higher Education. This process was conditioned by many internal and external factors, among which political orientation was the most important. The new trend of measures to build a more just and democratic society was exploited by it. The new governments that emerged after December 1992 elections set ambitious targets for mass education of the population.

The ultimate solution to the problem of political power marked the end of that period that is often seen in today's historiography as the phase of democratic change. From the time span viewpoint it coincides with the period of reform that represents one of the most interesting stages in the history of higher education post-communist Albania. It was the period when in Albania there was the possibility of freedom of thought and expression, of their diversity, the stage of illusions for the development of not only education but of the whole country in the path of free democracy. Fortunately, this period, in Albania, brought about the overthrow of many traditional norms and thoughts, paving the way for a more emancipated thought in addressing the fundamental problems of the time. In this spirit, the state and the Albanian public opinion discussed in broad terms, in addition to the problems of politics and economics, art and culture, and those of higher education and education in general, issues not only of form but also of content.

The subject of discussion became issues of theoretical and practical character: What would be the philosophy of change that higher education should have? What would be his mission and vision in relation to the formation of human capital (through learning); building knowledge bases (through research); distribution and use of knowledge (knowledge sharing); the sustainability of knowledge (through interbreeding memory, i.e knowledge transmission between generations), its impact on employment and sustainable economic development of the country, as well as integration into the European Higher Education Area (EHEA)? 


\section{A General Overview of the Main Demands and Major Currencies which Have Advanced the Development of Higher Education (1990 - 2013)}

Without removing the period, firstly, it would be appropriate in this research paper to re-evaluate the most significant economic, political and social factors that led to the transformation of the Albanian Higher School. In their multitude, design and implementation of reforms in higher education was the result of political directives, external factors and the democratic state authority. It was conceived as a process of change with powerful and direct influence in all other areas, and once as an important aspect of economic reforms and echoes of political and social change. As such, the reform aimed and implemented the restructuring of the entire existing higher education system, the institution's intent, the legal framework, the programs, the way of its management and financing. Undoubtedly, what is clear is that state activity for the transformation of the education system and the construction of a highly qualitative high school was determined and radical.

The changes were of a complementary, sequential and integral character and were extended to all levels of education and made the process irreversible as long as the democratic system continues.

Post-communist higher education developments wander with the general legality of the new political system. But directly or indirectly they were found under the influence of internal and external factors that at the last stage determined those specific trends and phenomena that set the Albanian seal. The starting point from a backward economic and social level in general and cultural educational in particular gets special values with the emergence of one of the most characteristic phenomena of the second decade, that of the fast-paced developments of massivization.

Overcoming the poor heritage even in the field of education remained a challenge. The individual, society and the state were interested in it. Ultimately, higher education serves the nation, and changes in this area are beneficial and so welcome. There were a number of real economic, educational, and cultural reasons and needs that determined the need for rapid changes of the albanian Higher School. In such a context, higher education policy must overcome these kinds of challenges.

\subsection{The First Set Of Challenges Is Related To The Inherited Level Of Higher Hducation}

In the period prior to 1990, higher education was oriented toward fast paths and shapes, conditioned by the difficulties of growth, but especially by the action of political factors, really strove the process and left an indefinite trace of recidivism. The most noticeable effect was the poor level of the teaching educational process.

"The knowledge provided by Albanian schools at all levels was insufficient, and it enabled for educated people, but less capable of orientation in practical life. Secondary and high-level specialists did not have the necessary skills to responding to the demands of economy" (Kambo, 2005)

Powerful influence also exerted defects of the model itself. Despite efforts to adjust the level and traditions of the Albanian school, it became a more or less mechanical transplant - the whole school and the education system was built based on the experience of the Soviet school. And along with the experience were carried the defects of the Soviet school, which in terms of Albanian education received greater loads in the report.

The nearly fifty years of Higher Education isolation in Albania has significantly influenced the quality of education and the comparability of higher education outcomes with other countries in the region. Primarily, higher education was only identified with the University of Tirana (UT).

By centralizing the issue of quantitative and qualitative development for the Albanian higher education, emphasis was placed on teaching, while other elements such as quality, research, services for society, the connection with economy, the development of academic staff, etc., were left out of focus. The unification of higher education with the UT and the lack of other higher education institutions for a long period of time created a series of problems in the relationship between the state and the university.

Momentum developments affected the future, making the mitigation of the consequences more difficult. 


\subsection{The second group of challenges is related to the transition phase.}

The current context in Albania was presented with these indicators: demand and supply for higher education, demand for knowledge and education, as well as the labor market and supply of knowledge. These indicators speak clearly about the state and level of higher education in Albania for the academic year 2001-2002. Here are some of them:

- "Percentage of students in relation to the number of people aged $18-22$ is $17 \%$.

- Higher non-university education* was attended only full time and by only $6,4 \%$ of the total number of students or $12,2 \%$ of the full time students.

- The ratio between the number of students and the number of pedagogues ranged from 18,8 to 19,8 students / pedagogues.

- The number of public and non-public HEl:

- Total: 11

- Universities: 8 (3 in Tirana, 5 in other districts) ${ }^{* *}$;

- Higher schools: $3^{* * *}$;

- Number of students enrolled in HEI full time and part time system:

- Total: 42.160;

- Full time system: 25.929;

- Part time system: 16.231.

- Pupils who received the diploma in public high schools:

- Total: 19.944 (femra: 10.869);

- Comprehensive High Schools: 17.249 (females: 9.932);

- Professional high schools: 2.695 (females: 937).

- Number of full-time teaching staff by grade:

- Proffesor: 250;

- Assistent proffesor: 303;

- PHD Lecturer: 268;

- Lecturer: 268;

- Assistant pedagogue: 542.

- Number of full-time teaching staff by degrees and titles:

- Scientific- Research Director: 3;

- Scientific- Research Senior: 6;

- Assistent Scientific- Research: 5;

- Public Expenditure on Education in 2001 in percentage versus:

- Budget Expenditures: 10.;

- Previous Year: 8"1.

Higher education in Albania during this period is characterized by a rigorous academic orientation and a "stay away from business" mentality, which did bring the desired balance between the supply of education programs and market demand. Strong sense of public status of higher education, aging of the population and brain drain from higher education to other activities or even emigration from the country were factors that negatively impacted on building a consensus for

\footnotetext{
* Higher non-university education represents a new element introduced in 1994 [Author's note].

** University of Tirana, Polytechnic University, University of Shkodra, University of Agriculture, University of Elbasan, University of Korça, University of Vlora, University of Gjirokastra [Author's note].

*** The Academy of Fine Arts, the High School of Nursing, the Institute of Physical Culture; not to mention the Higher Military Schools that are not under the Ministry of Education and Science. University of Agriculture, University of Elbasan, University of Korça, University of Vlora, University of Gjirokastra [Author's note].

${ }^{1}$ Institutit të Statistikave (INSTA), Vjetari statistikor 1993-2001, botim i Sektorit "Botim-Difuzionit", Tiranë: "R \& Advertising", 2003, f. 155-174. Arsimi. [Institute of Statistics (INSTAT), Statistical Annual Year Book 1993-2001, edition of the Department for Publication and Dissemination", Tirana: "R \& Advertising", 2003, pp. $155-174$. Education.]
} 
changes and adaptions to new realities. In addition, after 1999, governance in higher education was more centralized than ever before.

This picture helps us to realize that there were currently a number of challenges overcoming which required new policies from the Albanian state. As the economy and other areas, education has always been changing and moving because of its role in society, economic development and the responsibility that it has access to all the economic and social changes that occur at national and global level.

Equal access to a modern education system was also an important factor in promoting the development of modern economy, and this was the condition of the social welfare and equality of raising the welfare of minorities and other ethnic groups.

"In Albania, at an individual level, the education level was a decisive factor for increasing employability and ensuring an economic well-being. High levels of achievement in education stimulate innovation, self-employment and entrepreneurship in the country and essentially accelerate the process of knowledge transfer. For all these reasons, spending on education should be seen as an investment, the effect of which would be, first and foremost, a faster economic development. That is why governments in Albania should prioritize increasing public and private expenditure on education" (Malaj \& Fatmir Mema \& Sybi Hida, 2005).

Establishing a cooperation with the labor market was another challenge for higher education institutions in Albania. Step by step, the higher education system has created programs for the first level of study (Bachelor) as well as the programs of the second cycle of study (Master).

Given the ever-increasing importance of higher education in economic development, policies aimed at increasing participation in higher education were urgently needed to be built up and implemented.

Another challenge was the public and private sector financing of higher education in Albania. Time indicated that decision-making in public universities was carried out by the governing bodies and the nominees from it. Consequently, funding was also made by public funds, on the basis of force majeure. But this was not the case for private universities, where funding was made by the student choosing between various forms of education offer. In this way, these institutions were very active towards the service and the quality offered.

Current legislation, while providing academic freedom and autonomy for the university, did not actually provide a sufficient mechanism under which the university and the Ministry of Education and Science (MES)* could work together effectively to promote the development of modern institutions of higher education focused on results.

High professionalism was another challenge for higher education. HEls had no system of evaluating requests for student employment or other measures of wider character to evaluate teaching effectiveness and adapting study programs closely related to the labor market.

\subsection{The third group of challenges is related to the steps for integration into the European Higher Education Area (EHEA)}

The most difficult challenge has been and is to achieve Albania's integration into the European community. In this context, higher education is required to integrate into the European space. Law No. 9741, date 21.5.2007 " For higher education in the Republic of Albania" ${ }^{2}$ changed (with Law No. 323, date 12.11.2007; the decision of the Constitutional Court No. 6, date 19.3.2008; Law No. 1037, date 22.7.2010; Law No. 10493, date 15.12.2011)", led to a substantial change in the structure of higher education associated with Law Nr. 7810, date 6.04.1994 " For higher education

\footnotetext{
Nowadays Ministry of Education, Sports and Youth. [Author's note].

${ }^{2}$ Fletore Zyrtare e Republikës së Shqipërisë, Nr. 68, 16 qershor 2007, botimi Qendrës së Botimeve Zyrtare, Tiranë: "Grafon", 2007, f. 1917-1962. Material i botuar në faqen web site: www.qpz.gov.al [Official Journal of the Republic of Albania, No. 68, 16 June 2007, publication of the Center for Official Publications, Tiranë: "Grafon", 2007, pp. 1917-1962. Material published on the web site: www.qpz.gov.al]
} 
in the Republic of Albania" ${ }^{3}$ and Law No. 8461, date 25.02.1999 " For higher education in the Republic of Albania" ${ }^{4}$ and decision-making strategies.

However Law No. 9741 of year 2007 and all of its updates until December 2011, was compiled in accordance with the time developments in European higher education systems, underlines the need for a substantial change in the structure of higher education, with the only purpose that of the higher education system level Albanian to be reformed towards the objectives set by the Bologna Process.

Twenty years ago, higher education in Europe began to undergo a period of rapid transformation under the name of the Bologna process, a process that arose as a response to the massiveness of universities, internationalization and the pressure of global competition. To build the European Higher Education Space (EHES), European universities, as part of this process, underwent radical structural and cultural changes, with the main goals of increasing employment, promoting mobility of European citizens and enhancing the international competitiveness of European higher education.

In the period 1999-2005, the Republic of Albania has made a lot of efforts to join the European Union (EU) and trying as much as possible to bring any new law closer to European legislation. Such is the case of our country, where in one of the Articles of the Stabilization and Association Agreement ${ }^{5}$ the reform of higher education system in the country is also determined, based on the implementation of the Bologna Process objectives.

"The Parliament of Albania approved Law No. 9576, date 03.07. 2006 "For some additions and changes to the Law No. 8461, date 25.02.1999", who tried to set some rules for higher education, widely accepted by the Council of Europe member states, and reflected the fact that the Republic of Albania on 19 September 2003 officially signed the Berlin Declaration" (Papa, 2007).

Important in this regard was the adoption of the form and content of the Supplement (Diploma Supplement) diploma that had to be issued in higher education and, most importantly, the sanctioning was that of undergraduate studies at two levels (bachelor \& master) and assessed in credits ECTS (European Credit Transfer System).

Regarding the beginning of the quality assurance process in higher education in Albania, it can be dated back to July 1999 (Papa, 2007) ${ }^{6}$, just days after the signing of the Bologna

${ }^{3}$ Fletorja Zyrtare e Republikës së Shqipërisë, Nr. 5, 31 maj 1994, botimi Qendrës së Botimeve Zyrtare, Tiranë, 1994, f. 249-260. Material i botuar në faqen web site: www.qpz.gov.al; Shih: Kuvendi i Shqipërisë, Legjislacioni Shqiptar 1991-2000. Tregues Bibliografik Tematik (më tej: Legjislacioni Shqiptar 1991-2000 ...), Vëll. I, përgatitur nga: Zana Bufi, Vjollca Hysenbegas dhe Rudina Shiroka, Tiranë:, 2001, f. 47. [Official Journal of the Republic of Albania No. 5, 31 May 1994, publication of the Center for Official Publications, Tirana, 1994, pp. 249. Material published on the web site: www.qpz.gov.al; See: Albanian Parliament, Albanian Legislation 19912000. Thematic Bibliographic Index (hereinafter: Albanian Legislation 1991-2000 ...), Vol. I, prepared by: Zana Bufi, Vjollca Hysenbegasi dhe Rudina Shiroka, Tiranë:, 2001, pp. 47.]

${ }^{4}$ Fletorja Zyrtare e Republikës së Shqipërisë, Nr. 9, 16 mars 1999, botimi Qendrës së Botimeve Zyrtare, Tiranë, 1999, f. 273-286. Material i botuar në faqen web site: www.qpz.gov.al; Shih: K. Shqipërisë, Legjislacioni Shqiptar 1991-2000 ..., f. 47. [Official Journal of the Republic of Albania No. 9, 16 March 1999, publication of the Center for Official Publications, Tirana, 1999, pp. 273. Material published on the web site: www.qpz.gov.al; See: Constitution of Albania, Albanian Legislation 1991-2000 ..., pp. 47.]

${ }^{5}$ Fletore Zyrtare e Republikës së Shqipërisë Nr. 87, 14 gusht 2006, botimi Qendrës së Botimeve Zyrtare, Tiranë, 2006, f. 2955. Material i botuar në faqen web site: www.qpz.gov.al [Official Journal of the Republic of Albania, No. 87, 14 August 2006, publication of the Center for Official Publications, Trana, 2006, pp. 2955. Material published on the web site: www.qpz.gov.al;]

${ }^{6}$ Fletorja Zyrtare e Republikës së Shqipërisë, Nr. 24, 13 shtator 1999, botimi Qendrës së Botimeve Zyrtare, Tiranë, 1999, f. 893-894. Vendim i Këshillit të Ministrave Nr. 303, datë 1.7. 1999 "Për krijimin e sistemit të akreditimit në arsimin e lartë", u krijuan Këshilli i Akreditimit dhe Agjencia e Akreditimit. Material i botuar në faqen web site: www.qpz.gov.al [Official Journal of the Republic of Albania, No. 24, 13 September 1999, publication of the Center for Official Publications, Tirana, 1999, pp. 893-894. The Council of Ministers decision No. 303, date 1.7. 1999 "On the Establishment of Accreditation System in Higher Education", the Accreditation Council and the Accreditation Agency were established. Material published on the web site: www.qpz.gov.al;] 
Declaration, with the establishment of the Accreditation Council $(\mathrm{AC})^{*}$, as a collegial body that approves the assessment criteria at program and institutional level, compiled by the Agency for Accreditation of Higher Education (AAHE), which was established by a decision of the Council of Ministers No. 303, date 01.07.1999, " On the establishment of accreditation system in higher education ${ }^{7}$. Both of these institutions have collaborated and collaborate on quality enhancement, laying the basic foundations of a quality assurance system in Albanian higher education.

It should be noted that progress in the reform of higher education was slow, but, with the development of the private sector in higher education, year after year begins to show encouraging signs of a new teaching and learning approach to students.

The information society presents new demands on the skills that people need to possess, so there is a need for lifelong learning. Lifelong learning is the best way to satisfy the needs of the rapid change of society.

Exactly, our research paper is based on these three sets of challenges above mentioned. Within the historical context, analytically dealt with "evolution" of the issues and principles that have arisen as a need to change universities in society and their responsibility within the internationalization and global competition along the "integration in the European Space for Higher Education (EHES).

The research paper also aims at presenting the stages of change related to academic freedom and autonomy of Higher Education Institutions (HEI), reforms and their implementation, drafting strategies within the framework of the Bologna process, etc., based on the needs and demands of higher education to adapt to the ever-changing European and global environment, have been the challenges of our country, as well as part of the broad political, academic and social debate.

\section{Main Stages of Higher Education Development}

Political, economic, social and educational changes of Post-Communism conditioned developments in higher education. It representes the pyramid peak of each educational system, an important link, from the progress and the results of which it can be judged on the scale of progress for the entire Albanian society.

In the early 1990s it happened the imediate transformation from high schools to universities. The problems that emerged in this period were significant, the lack of a model, also working without a concrete guide of the steps to be followed with for realizing its reorganization was difficult. Given that higher education has mutual dependency with the social economical stages and it reflects the changes of our democratic superstructure policy, during the proces of its development has gone through two stages, from time perspektive, the intensity of changes and the expetations of results makes a difference from one to another.

During the first phase, from 1992 until 2003 were established the foundations of democratic higher education. During this period, Albania as a democratic state passed from a totalitarian state centralized to a legal, rule of law and a market economy. During this period, Albania as a democratic state passed from a totalitarian state centralized to a legal, rule of law and a market economy. And throughout this complex process involving every area of life and activity of the Albanian society, even higher education has already been realized a legal framework of international standards that laid the foundations for the development and consolidation of a

\footnotetext{
The Accreditation Council is a collegial body and consists of 9 persons, personalities in various fields of education, science and economics. [Taken from: Ministry of Education and Science (MoES), Accreditation Agency for Higher Education (hereinafter: Accreditation Agency...), Tirana, january 2005, pp. 1. A- Accreditation System].

7 MoES, Accreditation Agency..., pp. 1. Urdhër i Kryeministrit Nr. 171, datë 27.09.2010 "Për miratimin e strukturës dhe të organikës së Agjencisë së Akreditimit të Arsimit të Lartë". [MoES, Accreditation Agency..., pp. 1. Prime Minister's Order No. 171, date 27.09.2010 "To approve the structure and organization of the Agency for Accreditation of Higher Education".]
} 
democratic and European education.

I would mention here some of the great achievements of democratic governance in the years 1992-2003 related to the expansion of the network of higher education institutions nationwide. Në funksion të ecurisë së arsimit të lartë, institucionet shtetërore do priren drejt hapjes së disa Institucione të Arsimit të Lartë (IAL) edhe në rrethe të tjera të vendit.

\begin{abstract}
"After years of transition the period 1990-1994, was characterized by the open of universities, where state dominated and universities autonomy was in a non significant stage. The status "University" was owned by only two universities, which were followed by Politeknik University, after the divizion from University Of Tirana. Also in Tiranë functioned The Art Academy, The institute of phisical education and the Academy of Defence of Albanian Republic*. In Shkodra, Elbasan and Gjirokastra city it functioned Pedagogical Insitute which prepared teachers for higher education, meanwhile in Korcë it functioned Agricultural Institute" (Sota, 2017).
\end{abstract}

During this period scientific research was carried out partialy at universities, or in the Institute of the Academy of Science and in Institutes depending on the Central Institutes located in Tirana and other districts.

From 1992-1993, the High Pedagogical Institute of Elbasan ${ }^{8}$, the High Pedagogical Institute of Shkodra $^{9}$, the High Pedagogical Institute of Gjirokastra ${ }^{10}$ and the High Agricultural Institute of Korça ${ }^{11}$, received the status of the University with the decision of the Council of Ministers of the Republic of Albania. In 1994, Technological University "Ismail Qemali" was established in Vlora ${ }^{12}$.

The role and contribution of these undergraduate institutions in development has been confirmed by the involvement of a growing number of young people during the years 1994-2003. Still in this period private system did not pressure the public system, the gap which, both from the point of view of academic diversity, also from student admissions, was supplemented by the state system which expanded, but not related with the economic development of the country and the

\footnotetext{
* With the decision of the Council of Ministers No. 465, dated December 24, 1992, the institution was named General Headquarters Academy. In the decision of the Council of Ministers No. 37, dated 7 February 1994 The Academy was renamed the Academy of Defense of the Republic of Albania. In 1998, the Academy of Defense was admitted full-fledged member of the Consortium of Defense Academies and institutes of study and assurance of NATO member countries and PfP. By the Decision of the Council of Ministers of the Republic of Albania Nr. 180 dated 10.04.2004, the Academy of Defense was named the Spiro Moisiu Defense Academy. From 01.10.2012 the Academy received the name of the Academy of Armed Forces pursuant to the decree of the President of the Republic of Albania No. 7458, dated 11.05.2012. "The Organizational Structure of the Armed Forces of the Republic of Albania" consisted of 2 Faculties: Faculty of Security and Defense, (former Spiro Moisiu Defense Academy), Foreign Language Center, and the Faculty of General Education (former Military Academy "Skanderbeg") [Taken from: "History of Academies and Military Schools", in: Wikipedia - Free Encyclopedia, material published on the web site: https://tradoc.mil.al/index.php/en/akademia- e-fa / 2Uncategorised].

8 "Universitetit i Elbasanit", në: Historiku i Universitetit "Aleksandër Xhuvani" Elbasan, krijuar nga a.b.p., 2018. Material $i$ botuar në faqen web site: http://www.uniel.edu.al/index.php/historiku/237-historiku-i-universitetit ["University of Elbasan", in: History of The University "Aleksander Xhuvani" Elbasan, created by a.b.p., 2018. Material published on the web site: http://www.uniel.edu.al/index.php/historiku/237-historiku-i-universitetit]

${ }^{9}$ Grup autorësh, Universietti $i$ Shkodrës ndër vite, botimi i Universiteti "Luigj Gurakuqi" Shkodër, Shkodër: "Camaj - Pipa", 2002, f. 90. [Group of authors, University of Shkodra over the years, the publication of "Luigj Gurakuqi" University Shkodër, Shkodër: "Camaj - Pipa", 2002, pp. 90.]

10 "Universiteti i Korçës", në: Historiku i Universitetit "Fan. S. Noli" Korçë, Korçë, 2018. Material i botuar në faqen web site: http://www.unkorce.edu.al/sq/node/665 ["University of Korça", in: History of The University "Fan S. Noli" Korca, Korça, 2018. Material published on the web site: http://www.unkorce.edu.al/sq/node/665]

11 "Përshkrimi i shkurtër historik - UGJ-së", në Historikun i Universitetit "Eqerm Çbej" Gjirokastër, Gjirokastër, 20118. Material i botuar në faqen web site: https://www.uogj.edu.al/index.php?page=historiku-i-ugj ["Historical Description - UGJ", in: History of The University "Eqerm Çbej" Gjirokastër, Gjirokastër, 20118. the web site: https://www.uogj.edu.al/index.php?page=historiku-i-ugj]

${ }^{12}$ Grup autorësh, 10 vjet Universiteti "Ismail Qemali", Vlorë, botimi i Universiteti "Ismail Qemali" Vlorë, Vlorë: "Europrint", 2004, f. 3. [Group of authors, 10 years University "Ismail Qemali", Vlora, publication of "Ismail Qemali" University of Vlora, Vlora: "Europrint", 2004, pp. 3.]
} 
demand for specific professions.

The number of the students started to grow year after year, but massification was not a phenomenon and quality was not questioned yet. Education continued to belong to the "elite" and "elite' were the best students of high school, which passed many difficult tests to be accepted in universities.

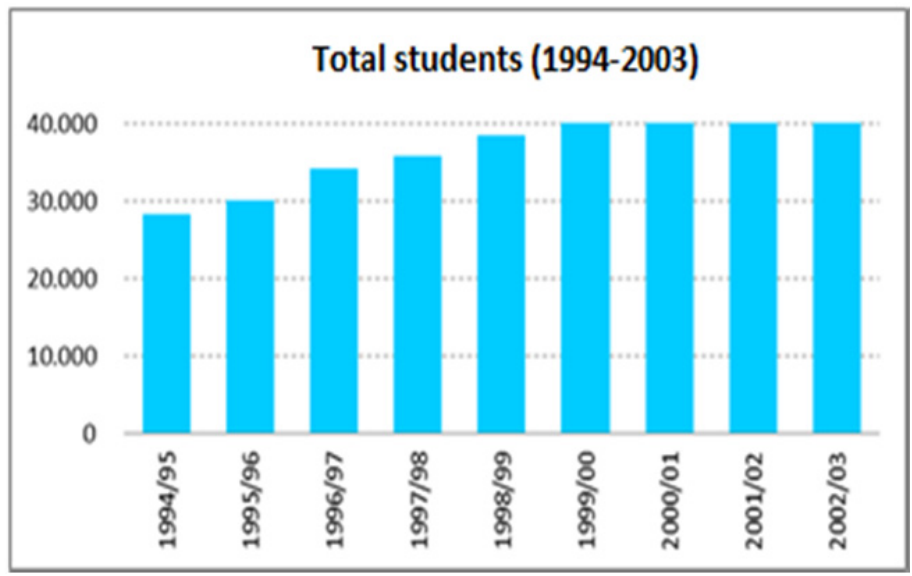

Graph 1: ${ }^{13}$ Students enrolled in Public Higher Education Institutions (1994 - 2003)

The impetuous character, mainly in the quantitative aspect of higher education development, during this period was associated with certain difficulties and weaknesses, from which the most important ones that can be mentioned are: relatively low quality level of teaching, lack of the base material, insufficient pedagogical frameworks and low level of qualification, mechanically applying often the traditional pedagogy depending to the experience of school without taking into consideration the concrete conditions of high school development and the new demands of the market economy.

The beginning of 2004 seemed to mark another important moment in the process of transition from the stage of laying the groundwork of the high democratic school to that of massification. Developments in quantitative aspect prepared for deepening the process and have undoubtedly contributed to the reduction of staffing requirements. Going forward to university was a necessity, which cannot be doubted. This passage, which was in the interest of the state and the population, was favored from some factors that led in the expansion and consolidation of higher education. If it will be compared to the previous period, it is easy to notice the big number of students enrolled in universities.

The number of applications in admission contests in Albanian universities has increased from over 20.000 students enrolled in the academic year 1994-1995, to around 120.000 students in $2009-2010^{14}$ (See Graph 2).

${ }^{13}$ Instituti i Shkencave të Shqipërisë (ASHA), "Zhvillimi i Arsimi të lartë në Shqipëri në periudhën 1991-2011", në: Open Data Albania, publication of Albania Institute of Science 7 years ago, kontribues: Blerta Zilja, Tiranë, $f$. 1. Material i botuar në faqen web site:http://open.data.al/sq/lajme/lajm/lang/sq/id/126/Zhvillimi-i--Arsimit-te-Lartene-periudhen-1991-2011 [Albania Institute of Science (AIS), "Development of Higher Education in Albania in 1991-2011", in: Open Data Albania, publication of Albania Institute of Science, contributor: Blerta Zilja, Tiranë, $f$. 1-3. Material published on the web site: http://open.data.al/sq/lajme/lajm/lang/sq/id/126/Zhvillimi-i--Arsimit-teLarte-ne-periudhen-1991-2011]

${ }^{14}$ Instituti i Shkencave të Shqipërisë (ASHA), "Arsimi i lartë në Shqipëri", në: Open Data Albania, publikim $i$ Albania Institute of Science, Tiranë, f. 1-3. Material $i$ botuar në faqen web site: open.data.al [Albania Institute of Science (AIS), "Higher Education in Albania", në: Open Data Albania, publikim i Albania Institute of Science, Tiranë, f. 1-3. Material published on the web site: open.data.al] 


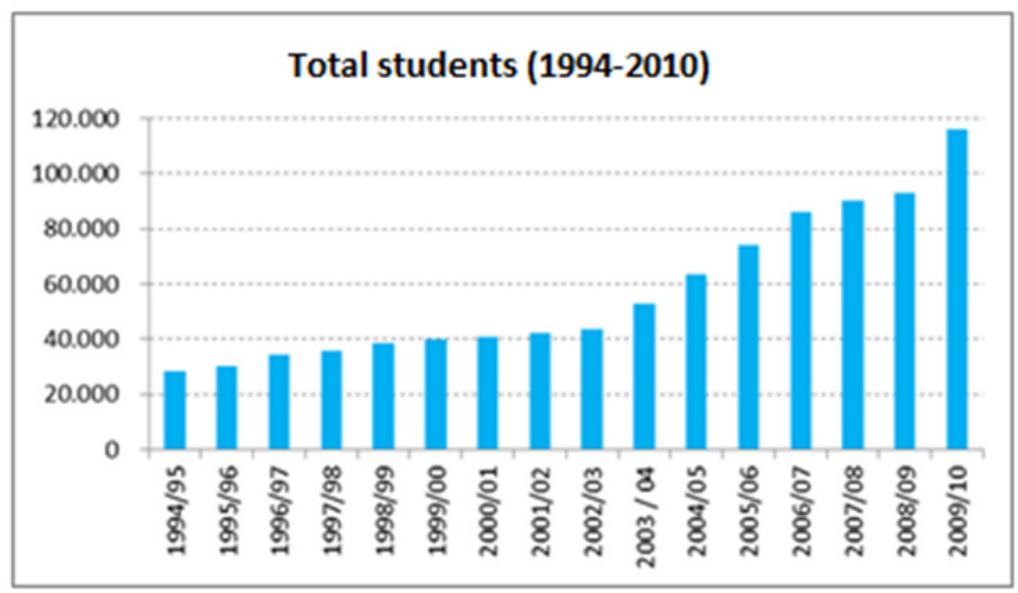

Graph 2: ${ }^{15}$ Students enrolled in Public Higher Education Institutions (1994 - 2010)

Meanwhile, during this period, higher education in Albania experienced developments in expanding the network of private wash education institutions. To understand some of these developments, we highlight some indicators of the number of these institutions during the period 2003/2004 to 2013. In the academic year 2003-2004, opened the first private university* in the country and since then, the number has always been increasing. For 2013, the number of Higher Education Institutions licensed by the Albanian state was 13 total $^{16}$.

This presentation brings to HEl's and the interest groups not only a complete information of the main and most important steps of the reform process (which is not complete in Albanian literature on higher education), but also serves to understand the changes and transformations that have taken place in the Albanian higher education system from year to year, within this process.

\section{Conclusions}

The new political, social and economical reality in Albania after the year 1990 is the starting point of the new changes and developments in the field of higher education. The isolation and the political developments of the communist dictatorship have resulted in a stagnation in development, which continued to be evident even during the period 1990-1992, with all the presence of some pozitive developments in this space.

The transformation of albanian higher education happened when Albania was going through a transition period. Albanian politics stated as important points a democratic life, development in economy, social politics to provide equal possibilities and to give justice to all ethnic and disadvantaged groups, integration of the state in evropian union as well.

In this frame, the system of higher education needs to be developed in a way in order to serve the new social order, to fill the national needs, the new realities and possibilities.

15 Ibid.

* In October 2002 the opening of "New York "Private University was inaugurated, a New York University branch with a four years bachelor'degree, with an economic profile, where the the first 110 students were enrolled. [Take from: INSTAT, Statistical Annual Year Book 1993-2001, pp. 157]. [In October 2002, the opening of the four-year New York University Private University was inaugurated, with the New York University branch affiliated with the first 110 students. [Take from: INSTAT, Statistical Yearbook 1993-2001, pp. 157]

${ }^{16}$ Ministria e Arsimit dhe Sportit (MAS), Raporti vjetor 2013, botim i Agjencisë Publike e Akreditimit të Arsimit të Lartë, Tiranë, janar 2014, f. 11. [Ministry of Education and Sports (MoES), Annual Report 2013, Publication of the Public Agency for Accreditation of Higher Education, Tirana, January 2014, pp. 11] 
It is clear that there are no easy and fast choices for the development of the higher education system in Albania, despite the several problems and the will to make changes. This is why the higher state institutions have established a systematic approach to changes including all the relevant factors in society in this process. Starting from this establishment, solutions were looked in order to make possible that our country is inseparable from the European space of higher education and defined with the goals of the Bologna Process. In this context, while building a qualitative and flexible system of higher education, which fulfils the requirements of the society, premises will be created that the higher education will be in the function of the stable development of society.

In accordance with the law of higher education, the ministry of education and science was responsible for planning the development of higher education in Albania during the period 19922013. In the frame of fulfilling this responsibility, the ministry of education and science undertook the implementation of a strategy for the development of higher education in Albania with a seven years perspective (2008-2015) and with the participation of international factors. The goal of this politics is the contribution in building a modern system of the higher education in Albania and creating a promoter of development for the country and the integrated efforts. In the frame, it establishes the realization points of the changes and development. The task is challenging and it requires a full commitment from everyone who works in the higher education and who are interested in its development.

The Albanian state stimulated and supported financially the expansion of institution of higher education, preparation of pedagogical and scientific staff, their qualifications and increase and strengthen the teaching and didactic base. This emphasized support during the studied period was connected to the political factors, academic and scientific community, students, civil society, the groups which were interested in education and the mass public for a clear, articulated vision of what kind of higher education is wanted and it sketched the path in order to fulfil our strategic objectives.

The education policy reflected in the legislation of these years would outline the appearance of the future education system. The vision of this formalized system, firstly in the first constitution after the year 1990 and later in the different laws of higher education during the years 1994-1999, would take a full appearance and physiognomy in 2000-2013.

\section{References}

Grup autorësh (2004): 10 vjet Universiteti "Ismail Qemali", Vlorë, botimi i Universiteti "Ismail Qemali", Vlorës, Vlorë: "Europrint" [Group of authors, 200410 years University "Ismail Qemali", Vlora, publication of "Ismail Qemali" University of Vlora, Vlora: "Europrint"]

Grup autorësh (2002): Universietti i Shkodrës ndër vite, botimi i Universiteti "Luigj Gurakuqi" Shkodër, Shkodër: "Camaj - Pipa"] [Group of authors (2002): University of Shkodra over the years, the publication of "Luigj Gurakuqi" University Shkodër, Shkodër: "Camaj - Pipa", 2002]

"Fletore Zyrtare e Republikës së Shqipërisë, Nr. 68, 16 qershor 2007, botimi Qendrës së Botimeve Zyrtare, Tiranë: "Grafon", 2007. Material i botuar në faqen web site: www.qpz.gov.al [Official Journal of the Republic of Albania, No. 68, 16 June 2007, publication of the Center for Official Publications, Tiranë: "Grafon", 2007. Material published on the web site: www.qpz.gov.al]

Fletorja Zyrtare e Republikës së Shqipërisë, Nr. 5, 31 maj 1994, botimi Qendrës së Botimeve Zyrtare, Tiranë, 1994. Material i botuar në faqen web site: www.qpz.gov.al [Official Journal of the Republic of Albania No. 5, May 1994. Law No. 7810, date 6.04.1994 " For Higher Education in the Republic of Albania". 46 articles. Material published on the web site: www.qpz.gov.al]

Fletorja Zyrtare e Republikës së Shqipërisë, Nr. 9, 16 mars 1999, botimi Qendrës së Botimeve Zyrtare, Tiranë, 1999. Material i botuar në faqen web site: www.qpz.gov.al [Official Journal of the Republic of Albania No. 9. March 1999. publication of the Center for Official Publications, Tiran, 1999. Material published on the web site: www.qpz.gov.al]

Fletorja Zyrtare e Republikës së Shqipërisë, Nr. 24, 13 shtator 1999, botimi Qendrës së Botimeve Zyrtare, Tiranë, 1999 [Official Journal of the Republic of Albania, No. 24, 13 September 1999, publication of the Center for Official Publications, Tirana, 1999]

Fletore Zyrtare e Republikës së Shqipërisë Nr. 87, 14 gusht 2006. botimi Qendrës së Botimeve Zyrtare, Tiranë, 2006. Material i botuar në faqen web site: www.qpz.gov.al [Official Journal of the Republic of Albania, No. 87, 14 August 2006, publication of the Center for Official Publications, Tirana, 2006. Material published on the web site: www.qpz.gov.al] 
Golemi, Bardhyl: "Reforma në shkollën e lartë, konsiderata të përgjithshme", në: Revista Pedagogjike, Nr. 4/2002, botim i Institutit të Studimeve Pedagogjike, Tiranë: "Erik", 2002] [Golemi, Bardhyl: "Reform in Higher School, General Considerations", in: Pedagogical Journal,, No. 4/2002, publication of the Institute of Pedagogical Studies, Tirana: "Erik", 2002]

"History of Academies and Military Schools", in: Wikipedia - Free Encyclopedia, material published on the web site: https://tradoc.mil.al/index.php/en/akademia- e-fa / 2-Uncategorised]

Institutit të Statistikave (INSTA): Vjetari statistikor 1993-2001, botim i Sektorit "Botim-Difuzionit, Tiranë: "R \& Advertising", 2003 [Institute of Statistics (INSTAT).: Statistical Annual Year Book 1993-2001, edition of the Department for Publication and Dissemination", Tirana: "R \& Advertising", 2003]

Kambo, Enriketa (2005): Arsimi në Shqipëri 1945-1960, botim Institutit të Historisë në Akademinë e Shkencave të Shqipërisë dhe, Tiranë: "Mësonjëtorja" [Kambo, Enriketa (2005) Education in Albania 1945-1960, edition of the Institute of History at the Academy of Sciences of Albania and Tirana: "Mësonjëtorja"]

Kuvendi i Shqipërisë: Legjislacioni Shqiptar 1991-2000. Tregues Bibliografik Tematik, Vëll. I, përgatitur nga: Zana Bufi, Vjollca Hysenbegas dhe Rudina Shiroka, Tiranë, 2001 [Albanian Parliament: Albanian Legislation 1991-2000. Thematic Bibliographic Index, Vol. I, prepared by: Bufi, Zana; Hysenbegasi, Vjollca end Shiroka, Rudina; Tiranë, 2001]

Instituti i Shkencave të Shqipërisë (ASHA), "Zhvillimi i Arsimi të lartë në Shqipëri në periudhën 1991-2011", në: Open Data Albania, publication of Albania Institute of Science 7 years ago, kontribues: Blerta Zilja, Tiranë, f. 1. Material i botuar në faqen web site:http://open.data.al/sq/lajme/lajm/lang/sq/id/126/Zhvillimi-i--Arsimitte-Larte-ne-periudhen-1991-2011 [Albania Institute of Science (AIS), "Development of Higher Education in Albania in 1991-2011", in: Open Data Albania, publication of Albania Institute of Science, contributor: Blerta Zilja, Tiranë, f. 1-3. Material published on the web site: http://open.data.al/sq/lajme/lajm/lang/sq/id/126/Zhvillimi-i--Arsimit-te-Larte-ne-periudhen-1991-2011]

Malaj, Arben; Mema, Fatmir and Hida, Sybi: "Albania, Financial Management in the Education System: Higher Education", in: EconStor (Make Your Publications Visible), BERG Working paper series on government and growth, No. 54, Bamberg University, Bamberg, 2005

Ministria e Arsmit dhe Shekncës (MASH): Angjencia e Aktreditimi të Arsmit të Lartë, Tiranë, 2005 [Ministry of Education and Science (MoES): Accreditation Agency for Higher Education, Tirana, 2005]

Papa, Leticia: "Legjislacioni shkollor në vendet e BE dhe në vendin tonë", në: Revista Pedagogjike, Nr. 3/2007, botim i Institutit të Studimeve Pedagogjike, Tiranë: "Erik", 2007 [Papa, Leticia: "School legislation in EU countries and in our country", in: Pedagogical Journal, No. 3/2007, edition of the Institute of Pedagogical Studies, Tiranë: "Erik", 2007]

Sota, Jani (2017): "University Education and Historical Studies in Albanian Area (1990-2015)", in: International Conference on Interdisciplinary Social Sciences (16-17 June 2017, Hungary, Budapest), Book of Proceedings with Abstracts of the International Conference on Interdisciplinary Social Sciences, London: "Richtmann Publishing LTD"

"Përshkrimi i shkurtër historik - UGJ-së", në: Historikun i Universitetit "Eqerm Çbej" Gjirokastër, Gjirokastër, 20118. Material i botuar në faqen web site: https://www.uogj.edu.al/index.php?page=historiku-i-ugj ["Historical Description - UGJ", in: History of The University "Eqerm Çbej" Gjirokastër, Gjirokastër, 20118. the web site: https://www.uogj.edu.al/index.php?page=historiku-i-ugj]

"Universitetit i Elbasanit", në: Historiku i Universitetit "Aleksandër Xhuvani" Elbasan, krijuar nga a.b.p., 2018. Material i botuar në faqen web site: http://www.uniel.edu.al/index.php/historiku/237-historiku-i-universitetit ["University of Elbasan", in: History of The University "Aleksander Xhuvani" Elbasan, created by a.b.p., 2018. Material published on the web site: http://www.uniel.edu.al/index.php/historiku/237-historiku-iuniversitetit]

Grup autorësh (2002). Universietti i Shkodrës ndër vite, botimi i Universiteti "Luigj Gurakuqi" Shkodër, Shkodër: "Camaj - Pipa" [Group of authors. 2002 University of Shkodra over the years, the publication of "Luigj Gurakuqi" University Shkodër, Shkodër: "Camaj - Pipa"] 